\title{
Anabases
}

ANABASES Traditions et réceptions de l'Antiquité

$18 \mid 2013$

Varia

\section{A “confucian” Epaminondas in Meiji Japan}

Chiara Ghidini

\section{(2) OpenEdition}

\section{Journals}

Electronic version

URL: http://journals.openedition.org/anabases/4337

DOI: 10.4000/anabases.4337

ISSN: 2256-9421

\section{Publisher}

E.R.A.S.M.E.

\section{Printed version}

Date of publication: 1 October 2013

Number of pages: 47-58

ISSN: 1774-4296

\section{Electronic reference}

Chiara Ghidini, «A "confucian" Epaminondas in Meiji Japan », Anabases [Online], 18 | 2013, Online since 01 November 2016, connection on 20 October 2019. URL : http://journals.openedition.org/ anabases/4337 ; DOI : 10.4000/anabases.4337 
Anabases 18 (2013), p. 47-58

\section{A “confucian" Epaminondas in Meiji Japan}

Chiara GHidini

The opening Ceremony of the exhibition on "Alexander the Great: East-West Cultural Contacts from Greece to Japan", held in Tokyo at the National Museum in August 2003, was the event that prompted my personal interest in the reception of ancient Greek History in modern Japan. In his address, the Greek ambassador Kyriakos Rodoussakis emphasised the role of a famous Greek - Irish - Japanese writer, Lafcadio Hearn (1850-1904), who "intuitively traced some of the similarities of Greco-Indian or Aryan-Indian cults with those of Japan." The main goal of the exhibition, whose catalogue was edited by the renowned scholar Tanabe Katsumi, seems to have been that of showing Alexander's influence even on Japanese religious art ${ }^{1}$.

However, in a critical article in the Japan Times, provocatively entitled "Alexander the Who?", Victoria James stresses how the last section of the exhibition, devoted to the links between the Buddhist cultures of Japan and of Gandhara, is meant to provide "a little local context for Japanese gallerygoers ${ }^{20}$. One of the reasons why this exhibition did not take much on the Japanese public can be due to the fact that Alexander the Great does not feature prominently in the curricula of Japanese schools. Alexander is undoubtedly one of the most "received" figures of Greek history, but it is a different Greek hero, Epaminondas, that became popular in modern Japan.

1 K. TANaBe, Alexander the Great: East-West Cultural Contacts from Greece to Japan, Tōkyō, NHK Promotion, 2003.

2 V. JAMES, "Alexander the Who? Face to face with history's greatest", Japan Times, Wednesday, Aug. 27, 2003 (url: http://www.japantimes.co.jp/culture/2003/08/27/arts/ face-to-face-with-historys-greatest/\#.UX5UJis2ytg). 
In past centuries, the nation has represented a complex political form, necessary, both in Europe and Japan, to bring together a particular population within a potentially hostile world, to establish emotional ties which would make up for the ongoing change, and to push such a population onto the path of progress. In early-mid Meiji 明治 Japan (1868-1912), the literary practice of the seiji shōsetsu 政治小説, or political novel, has played a crucial role within the process of national formation and thus of participation to modernity, placing strong emphasis on the value of other countries' socio-political institutions and on their hoped-for application within the Japanese context.

The need to construct a modern nation could not overlook issues related to history and historiography. After the Meiji Restoration (Meiji ishin 明治維新, 1868), Japanese scholars began to view and narrate history as a progressive process, following 19th-century European historiography ${ }^{3}$. Intellectuals educated in traditional forms of thought, facing a global world of nation-states, sought for different ways of dealing with the legacies of the past in response to this new world. Within the debate on history and historiography, Meiji political novel played a crucial role. As Christopher Hills has recently stated:

The rise and fall of the Meiji political novel, a largely forgotten episode in Japanese literature, was closely connected to attempts to devise new ways of representing history and the battles over the meaning of the events of 1868 that dominated political and intellectual life in the middle of the Meiji era ${ }^{4}$.

The fact that there are hardly any English translations seems to imply that the Meiji political novel has been excluded, both within and outside Japan, from the "canon" of modern Japanese literature. Yet, the Meiji political novel was enthusiastically received in its own times. In this sense, its re-consideration seems more than legitimate, especially since it grew out of the campaigns for democracy of the 1870s and 1880s known as the Freedom and Popular Rights Movement (Jijū minken undō 自由民権運動), according to which the Meiji government had usurped what should have been the democratic outcome of the fall of the Tokugawa ${ }^{5}$. Inspired by English political novels translated during those years, and in particular by Benjamin Disraeli's Coningsby (1844), the seiji shōsetsu had a short life, but did inform an interesting

3 See D. STEGeWERns, Nationalism and Internationalism in Imperial Japan: Autonomy, Asian Brotherhood, or World Citizenship?, London, Routledge, 2003, p. 60-63.

4 C. Hill, "How to write a Second Restoration: The Political Novel and Meiji Historiography", The Journal of Japanese Studies, v. 33, n. 2, Summer 2007, p. 337.

5 The Jiyu minken undō started in 1874 thanks to Itagaki Taisuke and other samurai who did not accept Meiji oligarchy's policies. The movement included village leaders, peasants, wealthy merchants, and, later on, also women. In 1880 the government rejected the demand by Ôsaka's Congress of People's Rights for the immediate establishment of a national assembly, and limited the convening of public meetings. Itagaki's liberal party dissolved in 1884. 
cultural shift, one which, connecting the political element with the narrative one, contributed to the development of a different evaluation of fictional writing, which came to gain new respectability because it conveyed important notions along with socio-political vocations. Also, some seiji shōsetsu crossed Japan's borders and were very successful in China and other Asian countries. Such was the case with Kajin no kigū 佳人の奇遇 (Chance Encounters with Beautiful Women, 1885-1897), an unfinished novel by Shiba Shirō 柴四郎 (whose nom de plume Tōkai Sanshi 東海散士 means "Unemployed Literatus from the Eastern Sea"), centred on the American war of independence. Kajin no kigu was translated in Chinese by Liang Qichao 梁髚超, eminent intellectual from the late Qing 清 dynasty (1644-1911), before he went into exile in Japan (1898), after the repression of the One Hundred Days' Reform (bairi weixin 百日維新) that he had supported together with his mentor Kang Youwei 康有 ${ }^{6}$. This novel would then inspire the verses entitled Độc Giai nhân kỳ ngộ (Reading Kajin no kigu ) of a famous nationalist from Vietnam, Phan Châu Trinh, and would be partially translated in Vietnamese from Liang's Chinese version, in order to encourage potential readers to embrace the cause of people's rights ${ }^{7}$. Also Yano Ryūkei's 矢野竜渓 Sēbe meishi. Keikoku bidan 齊武名士經國美談 (Young Politicians of Thebes: Inspiring Instances of Good Statesmanship, 2 volumes, 1883-4), included in the list of books owned by Kang Youwei, caught the attention of Liang Qichao, who decided in favour of a Chinese translation of the work.

In his Keikoku bidan, Yano Ryūkei (or Yano Fumio 矢野文雄, 1850-1931) chose to use ancient Greece, and in particular Thebes, in order to show a political model which could function as inspiration for Japan's rights movement. His narration of Thebes' rise follows a methodological filter connected with Victorian England, a nation that many Japanese intellectuals of the time considered with attention and admiration.

It is known that in the Edo period (1603-1867) contact with other cultures had been restricted by the sakoku 鎖国 policies, which implied death penalty for those who travelled overseas without bakufu 幕府 permission. Much of Western knowledge had entered Japan through the Dutch, and the development of rangaku 蘭学, or Dutch Learning, had stirred a strong interest in that culture. Less developed was the interest Japanese showed towards England, which appeared only seldom in Japanese works written between the 17 th and the 18 th centuries.

6 Liang translated Kajin no kigū in his political journal Qingyi bao 清議報 (Discussion in China) from 1888 to 1890 . For a study on Liang Qichao and his vision of history, see X. TANG, Global Space and the Nationalist Discourse of Modernity: the Historical Thinking of Liang Qichao, Stanford, Stanford University Press, 1996. For a critical study on the transculturations of Japanese literary texts in China, Taiwan and Corea, see K. L. THOMBER, Empire of Texts in Motion: Chinese, Korean, and Taiwanese Transculturations of Japanese Literature, Cambridge, Mass., Harvard University Press, 2009.

7 On this topic, see S. Vĩnh (ed. by), Phan Châu Trinh and his Political Writings, Ithaca, Cornell University Press/SEAP Publications, 2009. 
At the end of the 18th century, however, England became object of attention and research, especially through the works of Honda Toshiaki 本多利明 (1744-1821):

When it comes to buildings, no country in the whole world can compete with England. [...] In these three capitals [London, Paris and Amsterdam] beautiful people live, people with no equal in the world. They have stone houses both in villages and cities, and even in the outskirts. They are two to five stories high and incredibly beautiful. How come that those who are from these three capitals, human beings as anybody else, have managed to reach such a level of excellence? It is because many centuries have passed since they became civilised, and because their political institutions are based on principles of natural government (shizen jidō自然治道) (Seiiki monogatari 西域物語, 1798) ${ }^{8}$.

His account is certainly mythicised, but Honda was truly convinced that Japan could draw from England elements of growth both culturally and politically. He believed that colonisation was a must for rulers, and even in this respect his model was England, a comparatively small nation, just like Japan, but wealthy. He suggested military and economical models and encouraged Japan to implement political and institutional reforms, persuaded that the Japanese should adopt the Roman alphabet and move their capital on the Kamchatka peninsula, located, strangely enough, at the same latitude as London? .

The persuasion inherited from China, according to which the level of civilisation would decrease proportionally with the distance from the political and cultural centre, had pushed the Japanese to transform their archipelago into a central space even in cartographic representations. In time, the national geo-body ${ }^{10}$, resulting from the encounter of a territorial discourse with the modernisation of the technology of representation, that is to say of cartography, had undergone variations, oscillating between the perception of Japan as alternatively borderland and heartland. Well into the 19th century few Confucian scholars, such as Yokoi Shōnan 横井小楠 (1809-1868), while maintaining that Japan occupied a central geographic position, felt the need to study the West on the basis of Confucian thought. Shōnan soon became a passionate advocate of Westernisation, believing that Japan's common good would become accessible only by borrowing British and American political institutions. Towards the end of the 19th century, Japanese world maps showed increasing awareness of Japan's geopolitical non-centrality. Britain was still to represent a possible model, after which Japanese

8 Honda Toshiaki, "Seiiki monogatari”, in Kaiho seiryō, Tōkyō, Iwanami shoten, 1970.

9 On Honda Toshiaki see D. KeEne, The Japanese Discovery of Europe: Honda Toshiaki and Other Discoverers, 1720-1798, London, Routledge, 1952. More recently, H. P. VARLEY, Japanese Culture, Honolulu, University of Hawaii Press, 2000.

10 T. Winichakul, Siam Mapped: a History of the Geo-Body of a Nation, Honolulu, University of Hawaii Press, 1997. See also W.A. CALlaHAn, "The Cartography of National Humiliation and the Emergence of China's Geobody", Public Culture, vol. 21, num. 1, 2009, p. 141-173. 
could shape their body politic. Yet, liberal views were far from being left unpunished or uncensored, in preparation for the conservative turn taken by the government with the Bismarkian Meiji Constitution of $1889^{11}$.

Meiji political and cultural commitment involved a policy of "foreign borrowing", similar in its intensity to the borrowing from China experienced many centuries before. Some Japanese thinkers believed that the motivation for the power acquired by Western nations was especially political, and resided in their focus on freedom and equal rights, while others opted for a religious explanation, emphasising the crucial role played by Christianity. On a socio-cultural level, Meiji leaders promoted Western social customs and cultural trends, with the persuasion that adopting them would help the cause of Japanese civilisation and enlightenment (bunmei kaika 文明開化) ${ }^{12}$. Even though Western habits would become far more popular a few decades later, it is unquestionable that the Japanese landscape, and to a certain degree its mindscape, was being noticeably altered already in the late 19th century. External changes were accompanied by structural reforms, especially as regards education policies, with the introduction of compulsory education in $1872^{13}$. One of the most active advocates of modernisation through Western learning and education was Fukuzawa Yukichi 福澤 諭吉, who founded the Keiō gijuku 慶應義塾, a school that trained a great number of future intellectuals engaged in the promotion of Western political and economic institutions, including Yano Ryūkei.

It is useful mentioning a few crucial points related to Yano's political and literary activity, in order to better understand the intellectual choices made by the author of

11 Up to the promulgation of the Constitution, and shortly after, the Meiji government sought to become a rich country with a strong army, reforming tradition in order to raise Japan to the level of Western powers, whereby doing away with the unequal treaties established between the two in the 1850s, the beginning years of the so-called humiliation diplomacy. See C.L. Hsu "The All-Direction Diplomacy in Japan”, paper given at the conference Building On Our Past and Investing in Our Future: An International Seminar On Multidisciplinary Discourse, jointly organized by Fo Guang University, Taiwan and

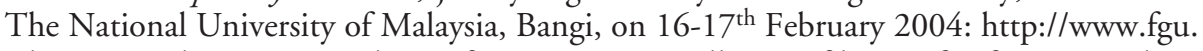
edu.tw/-academic/up1/malayconference1/paperscollection.files/conferefncepapers/hsu. pdf

12 The phrase "civilisation and enlightenment" was coined by Japanese supporters of Westernisation. See T. Morris SuZUKI, Re-Inventing Japan: Time, Space, Nation, Armonk, NY, M. E. Sharpe, 1998, p. 64.

13 French and British influences in Meiji Japan were quite significant: France was often the model of the Liberal Party. Germany was also influential, but it has been noted that much of the German influences have tended to justify statist, semi-feudal, and reactionary tendencies in Meiji Japan, thereby reinforcing Japanese deviance from liberal-democratic patterns of development. Meiji Constitution itself, as a matter of fact, was based on Bismarck's conservative views and has been conventionally understood as a rearguard action in the struggle between the Popular Rights Movement and the oligarchic elements in the government. 
Keikoku bidan. Yano began his political career at the Finance Ministry under Ōkuma Shigenobu 大隈重信. He left the government with Ōkuma in the political crisis of 1881 and became with him one of the organisers of the Constitutional Reform party (Rikken kaishintō 立憲改進党). In 1884, thanks to the unexpected sales of his Keikoku bidan, he could afford to go abroad. His stay in England, however, persuaded him that Japanese political consciousness was in an urgent need of further development, and so were its political parties. He was not wrong, for both the Liberal party and the Reformist party were destitute in that same year. With the formal demise of the party, Yano devoted his full energies to writing and journalism, then turned again to the government, first in the Imperial Household Ministry in a ceremonial capacity and later as ambassador to Beijing. In the late 19th and early 20th centuries, Yano briefly turned to socialism, joining Katayama Sen's 片山潜 Labour Movement in Japan. Katayama writes about Yano in his The Labour Movement in Japan (1918), saying:

Mr. Yano was an old liberal statesman and an influential agitator for the constitutional government in the eighties. But he left the liberal party because the party became too corrupt $^{14}$.

After reading Thomas More and Edward Bellamy, Yano published the utopian novel Shin shakai 新社会 (The New Society, 1902), a book that became quite popular and was interpreted by Katayama as an elaboration on the way to convert Japan into a socialist state.

Keikoku bidan was written when Yano was still an active militant in the Constitutional Reform party. Forced in bed by an illness, he decided to use his time to write a useful story, which could inspire young Japanese (males) to build a constitutional government. This effort resulted in the first volume of a political novel set in fourth-century Thebes, rather than in contemporary times, also in order to avoid censorship.

Promising youth plays a key role in Yano's political novel. In the first chapter, the author introduces a group of young boys with their elderly teacher, as they continue their education after school hours, learning instances of Greek wise kings and generals, who succeeded in relieving people's sufferings. In particular, the boys learn about Codrus, the last of the legendary kings of Athens, and Thrasybulus, the Athenian general, who led the democratic resistance to the oligarchic government of the Thirty Tyrants imposed on Athens by Sparta. Then the reader is told that these zealous boys include Pelopidas, Epaminondas, Melon ${ }^{15}$, Theopompus, Pherenikus, Phyllidas, Charon, Kephisodorus, and Damokleidas, and that all of them, probably thanks to their enthusiasm and education, would later become famous for their great deeds. In particular, Pelopidas, "a man of good character, will depose the Evil party of

14 Sen Katayama, The Labor Movement in Japan, Chicago, C. H. Kerr \& Company, ca 1918, p. 76.

15 See Xen, Hell. 5, 4, 2 ss ; Plut., VitaPelop. 8, 2 ; 11, 2 ; 13, 1 ; 25,4. 
Thebes, restore the Theban government and make of Thebes the leader of the Greek alliance of nations", while Epaminondas, "a man of profound generosity and skilled in military strategy, extending the power of the country, will defeat the formidable enemy ${ }^{16 "}$. The reader is also informed that the situation takes place in 394 B.C.E., the year when Thebes joins the confederation against Sparta. Then the narration moves to 382 B.C.E., when the young boys have grown up and Pelopidas, forced to flee after the instalment of a Spartan garrison in Thebes, goes into exile with others to Athens. The following pages of the first volume of Keikoku bidan are mainly concerned with the restoration of a democratic government in Thebes, which is achieved thanks to Pelopidas and Epaminondas. In the second volume, instead, Yano deals with the process whereby Thebes becomes a leading power in the whole of Greece, and underlines the meaning of the great battle of Leuctra in 371, interpreted not merely as an event concerning the display of power of Thebes, with its Sacred Band, and Sparta -Yano uses the metaphor of a lion fighting against a tiger-, but as one that marks for generations to come a great divide between democracy and despotism.

Yano's main aim, as he himself states in the preface to the book, was to take as model Japanese previous histories, which had encouraged in different times the restoration of the imperial rule, such as the Dai Nihonshi 大日本史 (History of Great Japan, conceived by Tokugawa Mitsukuni 徳川光图 and completed only after the Meiji restoration), the Nihon gaishi 日本外史 (Unofficial History of Japan, Rai San'yo 賴山 陽, 1827) and the Taiheiki 太平記 (Chronicle of the Great Peace, 14th century), and to write a type of historical novel, where the fictional part was meant as a compensation for the lack of historical details in the sources he consulted. As many early Meiji intellectuals, Yano had been trained to have, if not contempt, at least a defensive view of literature as something with a use, usually an instructive one. In this case, the author was probably writing for fellow reformists and for those young readers, who could eventually develop a more active interest in the extension of popular rights and in the support of the constitutional government.

In the preface to the book, Yano explicitly states that he intends to be as loyal as possible to the authentic history of ancient Greece, while letting the reader enjoy it in the form of a pleasant tale. His urge for accuracy is such that he chooses to compile a list of the modern historiographical sources used by him for a novel that represents an adaptation of ancient Thebes' history mediated by British historiography to the cultural settings of early Meiji Japan.

In the beginning of the second volume of Keikoku bidan, the author acknowledges ancient sources and mentions both Xenophon and Plutarch, whose works he supposedly read in their English translation. Mentioning the two ancient historians, however, Yano maintains that the first, living in the same years as Epaminondas, was

16 Translation from Keikoku bidan is mine. See Yano Ryūkei, Keikoku bidan, v.1, Tōkyō, Iwanami shoten, 2001, p. 55-56. 
probably very detailed in his historical accounts, but that, being a supporter of the Spartan system of rule by oligarchy, his main aim was, in fact, praising Sparta. In this sense, Yano adds, Xenophon's historical accounts can be considered unsatisfactory and biased. Plutarch, on the other hand, lived four centuries after Epaminondas and, in his will to write a history of Greek and Roman heroes, he ended up, Yano believes, giving much emphasis to Pelopidas, but very little to Epaminondas.

Yano's list of Western sources includes the historians John Gillies (1747-1836), Connop Thirlwall (1797-1875) and George Grote (1794-1871), the Danish scholar Ernst Frederik Bojesen (1803-64), George W. Cox (1827-1902), whose General History of Greece was based on Grote's, the British lexicographer William Smith (1813-1893), Alex Fraser Tytler (1747-1813), whose Elements of General History was translated in Japanese in 1869, thereby representing the first Universal History that appeared after the Meiji Restoration, and the American author, Samuel Griswold Goodrich (17931860), better known as Peter Parley and quite popular in Japan, since his works were also used as textbooks at school. Yano's mention of such a selected number of mainly British historiographical works seems to corroborate the idea that, after all, his priority should not be sought in his being accurate in terms of the ancient accounts of Thebes' rise, but in his effort to adopt a similar approach to the one employed by the historians, especially Grote, on whom his novel was explicitly based.

Carmine Ampolo, arguing in his Storie Greche that Germans and Britons felt rather inclined to the reconstruction of ancient Greece, mentions Piero Treves' introduction to Plutarch, in which he maintained that, unlike German Romantics, the British saw in ancient Greece "bipartitism, parliamentarianism, [...] and the existence of a civil community", the measure of whose "success" depended on the citizens' degree of freedom. Yano accepted the mid-Victorian persuasion, according to which ancient Greece represented the "ancestral embodiment of liberal freedom ${ }^{17}$ ", and found a great deal of inspiration for his political and cultural project in British historians, especially in Grote, whom Arnaldo Momigliano defined as the historian capable of combining passionate morality and political interests ${ }^{18}$. Yet, rather than following Grote's utilitarian rehabilitation of Athenian democracy, Yano preferred to emphasise the political achievements of "the small country" of Thebes, and focus first on Pelopidas, then on Epaminondas, heroes towards whom Grote himself showed at least sympathy ${ }^{19}$. A sentence like Grote's "these countrymen of Epaminondas and Pelopidas set an example of devoted self sacrifice in the cause of Grecian liberty ${ }^{20}$ " must have sounded extremely

17 P. Cartledge, "Ancient Greeks and modern Britons", History Today, vol. 44, 1994.

18 A. Momigliano, Contributo alla storia degli studi classici, vol. 1, Roma, Ed. di Storia e Letteratura, 1955, p. 222.

19 See The Cambridge History of English and American Literature in 18 Volumes, vol XII. "The Romantic Revival", ed. by A.W. Ward, A.R. Waller, W.P. Trent, J. Erskine, S.P. Sherman, and C. van Doren, Cambridge, Cambridge University Press, 1907-21. 
meaningful to Yano, since it entailed both patriotism, a necessary drive in the building of the Japanese nation, and the concept of liberty, one that activists within the reformist party seemed to deem as crucial, even though the term "liberty" had only very recently been imported from the West and translated into Japanese, a language which was itself undergoing significant changes at the time ${ }^{21}$.

The extent to which Japanese thinkers from early Meiji could actually understand the profound implications of concepts related to civil liberty is difficult to state. In the early 1870s, the first Japanese translation of John Stuart Mill's On Liberty by Nakamura Masanao 中村正直, one of the Meiji enlightened intellectuals, had come out, selling a great number of copies and becoming quite popular in the country. The term used by Nakamura to translate "liberty", jiju $\bar{u}$ 自由, had been often considered ambiguous, probably because in the English-Japanese Dictionary from 1862 it appeared as the Japanese translation of the English "freedom/liberty", but also contained a negative hue, in the sense of egoism/ licence, in its traditional sense ${ }^{22}$. Not only the concepts of civil or social liberty, but also those of individual and society were utterly new to Japan: in Nakamura's translation, civil and social liberty, first transcribed in the alphabet for foreign words, are rendered respectively as "freedom of the people" and "freedom related to the association based on human relations", an expression, the latter, meaning "society 23 ", and containing the term jinrin 人倫, used already at the end of the 19th century to translate the Hegelian notion of Sittlichkeit, "ethical life ${ }^{24 "}$.

21 The concept of writing that evolved in the Meiji era is known as genbun itchi 言文一 致 (unification of written and spoken language). As Karatani Kōjin has stated, genbun itchi represented the invention of a new conception of writing as identical to the spoken language (K. Karatani, B. DE BARY, Origins of Modern Japanese Literature, Durham, Duke University Press, 1993, p. 39).

22 A. Yanabu, Hon'yakugo seiritsu jijō (Background of the Establishment of Translated Words), Tōkyō, Iwanami shoten, 1982, p. 175-191. For a critical work on the term "liberty" in Japanese, see D. Howland, "Translating Liberty in Nineteenth-Century Japan", Journal of the History of Ideas, vol. 62, num. 1, 2001, p. 161-181. In the recent book by the conservative comparativist Kobori Kohichirō entitled Nihonjin no jiȳ no rekishi (Tōkyō, Bungei shunjū, 2010), the author dwells on the history of the term jizyu, aiming to emphasise the antiquity of its use, and maintains that such a term was already known to Murasaki Shikibu.

23 Meiji bunka zenshō, 5 v., Tōkyō, Nihon hyōronsha, 1927. Original English: "The subject of this essay is not the so-called 'liberty of the will', so unfortunately opposed to the misnamed doctrine of philosophical necessity; but civil, or social liberty: the nature and limits of the power which can be legitimately exercised by society over the individual." John Stuart Mill, On Liberty, New York, Penguin Classics, 1982, p. 59. (Cf. J.S. Mill: "The idea of a rational democracy is not that the people themselves govern, but that they have security for good government", p. 71).

24 See Shibue Tamotsu's translation of Hegel (in Rekishi kenkyūhō, Hakubunkan, 1894). The term society was rendered by Fukuzawa Yukichi as ningen kōsai in his translation of J.H. Burton's Political Economy. 
The technique employed by Yano in Keikoku bidan is that of the mirror. Yano expected the reader to find in the tyrannical rule of the Theban "evil" party led by Leontiades, the one in collusion with the militaristic state of Sparta, a parallel to the repression of the popular rights movement at the hands of the oligarchs. The alliance of Pelopidas' party - confucianly defined in the novel as the "correct party"- with Athens could entail, according to John Pierre Mertz, the possibility for the Reformist party and the Liberal party (identifiable with Athens) to co-operate, while the removal of the tyranny and Theban triumphant atmosphere in the Assembly hall ought to reflect the hopefully successful outcome of contemporary Japanese efforts aiming to promote a "moderate" democratic system, with the implementation of a national assembly to function as the public space of political legitimacy ${ }^{25}$.

Young and idealistic readers, fascinated by the theme, the historical facts, the architecture, and the narrative style of Yano's political novel, came to feel sympathy for the statesman appearing within the story. Their familiarisation with heroes belonging to a geographically and historically remote context was facilitated by Yano's skills as regards creative adaptation, a very popular literary trend in many fictional works dating to early Meiji Japan and inspired to European novels. To quote one example, Pelopidas' song Flowers of Spring, occurring in the eleventh chapter of the first volume, was so close in style and content to Meiji patriotic and encouraging songs, that young readers could easily feel inspired by it, so much as to actually learn it by heart:

If you gaze around, to the end of the fields, to the limits of the mountains, there is no village without (cherry) blossoms. They are all in full bloom. However, if you investigate their past, even these very flowers, whose scent and colour seem so lovely, have experienced nothing but sorrow. In the frosty mornings, their leaves are made to fall; in snowy nights, their tree branch is made to break. Gazed so intently that they could almost wither, these flowers have accumulated sorrow, and yet their endurance has proved worthwhile, for they have now met with tranquil spring and have beautifully bloomed. You have chosen to live for the sake of the world, so you should know that the glorious flowers of joy have sorrow. Then, why mourning? Indeed, the flowers of spring set the example. Indeed, the flowers of spring are beautiful ${ }^{26 !}$

Yano's book reached such great popularity that in 1892 Kawakami Otojirō 川 上音二郎, the first Japanese actor to appear in the West together with his successful wife Sadayakko 貞奴, produced and played the lead in the stage version of Young Politicians of Thebes "A Greek Historical Play". This dramatisation, while telling the life of Epaminondas of Thebes, was set in mid-nineteenth-century Japan and used

25 J.P. Mertz, Novel Japan: Spaces of Nationhood in Early Meiji Narrative, 1870-1888, Ann Arbor, Center for Japanese Studies The University of Michigan, 2003, p. 217.

26 R. YAnO, Keikoku bidan, v.1, Tōkyō, Iwanami shoten, 2001, p. 145-146. 
Japanese costumes: contemporary prints of Kawakami show actors in attitudes and settings closely resembling those of the kabuki 歌舞伎 27.

Epaminondas became widely known within the country, and many Japanese thought each Englishman should know about him. In his Japanese Plays and Playfellows (1901), Osman Edward mentioned how, in a conversation with an astonishingly freethinking Japanese woman, he was asked all sorts of questions about Western history, including his opinion on Caesar, Napoleon and Epaminondas, a hero, the latter, Edward admitted to recalling only very shadowy ${ }^{28}$.

Yano's adaptation worked on many levels. As enthusiastic as he could feel regarding the possibility of adopting British liberal concepts in Japan, he had been trained in a Confucian school before entering Fukuzawa's Keiō gijuku, and was still heavily influenced by Confucian ideals. The three ancient heroes from Thebes, Pelopidas, Epaminondas and Melon, were thus adjusted to the Japanese context and came to

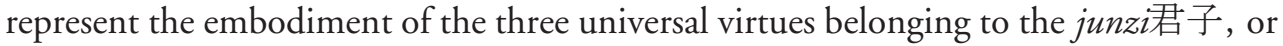
the exemplary man according to Confucianism: wisdom, humanness or benevolence, and courage.

The ending of the novel itself is a farther proof of Yano's Confucian, or neoConfucian, upbringing:

In the span of nineteen years, these eminent Thebans did away with tyranny inside their country and extended their power outside. Dear readers, bear in mind that a new prosperous country should be ruled with the balance of tolerance and strictness ${ }^{29}$ !

The final sentence is almost directly taken from a work by one of the most famous Chinese neo-Confucian thinkers, Zhu Xi 朱喜 (1130-1200), entitled Song ming chenyan xing lu 宋名臣言行錄 (Records of the Words and Deeds of Fine Statesmen in Song Dynasty; in Japanese: Sō meishin genkō roku) ${ }^{30}$. This work is an anthology of anecdotes about Northern Song martyrs meant for use in teaching political ethics, and it seems that the Meiji Emperor himself used to read it aloud with a group of subjects at court.

Although it is often ignored that all thinkers active in the civilisation and enlightenment movement had been educated in Chinese philosophy and in the Chinese classics, Neo-Confucian influence on many political activists in early Meiji Japan is truly undeniable. Yano was not alone in blending different cultural and linguistic elements, some of which do resemble those employed by earlier Tokugawa writers focusing on

27 For a study on theatre adaptation in Japan, see for ex. S. LiU, "Adaptation as Appropriation: Staging Western Drama in the First Western-style Theatres in Japan and China", Theatre Journal 59, 2007, p. 411-429.

28 O. Edward, Japanese Plays and Playfellows, Kessinger Publishing, 2004, p. 156.

29 R. YANO, Keikoku bidan, v.2, Tōkyō, Iwanami shoten, 2001, p. 310.

30 ZHU Xi, Song ming chen yan xing lu, Taipei, Taiwan shang wu yin shu guan, 1983. 
loyal samurai stories such as Kyokutei Bakin 曲亭馬琴 and his Hakkenden 八犬伝 (The Accounts of the Eight Dogs, 1814-41). Even a translator and scholar like Nakamura Masanao, one of the most eager promoters of Western ideas, never denied his Confucian background. On the contrary, he believed that despising China would only be a sign of "petty superficiality", the sort of superficiality that can "destroy a nation". Acknowledging Japan's cultural debt to Chinese thought, Nakamura attempted to find some common ground between Western and Confucian moral attitudes, stating that "As far as individual morality is concerned, regardless of past and present, East or West, in the end, the main principle is one thing called self-governance [...], which is the source of the principle of freedom ${ }^{31}$ ". He also added that both ancient Greek and Confucian wisdom, starting with Mencius, viewed human nature as basically good. By bringing together different systems of thought, Nakamura meant to avoid a drastic break with tradition, one which had been advocated by other (more liberal) intellectuals with a similar traditional upbringing.

Borrowing from historians like Grote, who turned ancient Greeks into contemporary people, Yano turned the Theban and Pythagorean Epaminondas into a Japanese young man from the late nineteenth century, rooted in Confucian moral values and eager to see his reformist political views realised. In Yano's analogy, the Theban hero becomes a Japanese national hero, who, after the stabilisation of the country through the implementation of a democratic constitutional monarchy, can eventually set off to make of Japan the hegemonic power in the rest of Asia.

Early Meiji represented a transitional period, one in which, rather than the model of the transnational conqueror, the one more likely to be perceived as significant was that of the national cultural hero. In this sense, Epaminondas could best satisfy early Meiji's needs and expectations, as the paradigm of national political maturity and internationally recognised political authority.

Chiara Ghidini

Lecturer in Japanese Studies and East Asian Religions

University of Naples "L'Orientale "

Department of Asia Africa and the Mediterranean

Piazza San Domenico Maggiore

80134 Naples, Italy

cghidini@unior.it

31 Nakamura Masanao, "China should not be despised", in C. Gluck, A. E. Tiedemann, Sources of Japanese' Tradition: 1600 to 2000, New York, Columbia University Press, 2006, p. $49-51$. 